\title{
VIETNAM
}

\section{Relief to civilian and military victims}

Last March International Review published the text of an appeal launched jointly on February 9, 1968, by the International Committee of the Red Cross and the League of Red Cross Societies on behalf of the civilian population in the Republic of Vietnam and the Democratic Republic of Vietnam. We mentioned then that the first donations had begun to pour in and that distribution of relief supplies received had started immediately.

Since that time donations have continued to reach beneficiaries and the two international institutions of the Red Cross have issued a progress report on assistance to civilian and military victims as of May 1968. This report to National Societies will no doubt be of interest to our readers, who will see from the extracts given below how extensive is the general relief work undertaken by the Red Cross in Vietnam.

\section{Republic of Vietnam}

\section{LEAGUE PROGRAMME}

From the joint circulars issued by the League and the International Committee of the Red Cross on the 12th February and 26th March National Societies are informed of the emergency assistance that has been provided through Red Cross channels for the victims of the Têt offensive. The hundreds of thousands of persons who were displaced as a result of the extensive military operations of the end of January and early February have swelled the number of "refugees" in this war-torn country. The first emergency period is over and the Republic of Vietnam Red Cross, 


\section{IN THE RED CROSS WORLD}

with the assistance of the League Delegation, is now concentrating once again on developing its relief organisation in the Provinces. This programme it will be recalled foresees the distribution of rations, the operation of fixed and mobile dispensaries, as well as milk stations for the children, training of Red Cross volunteers and the establishment of regional warehouses. The value of such a programme was amply demonstrated by the immediate assistance which the existing Provincial Red Cross Committees were able to provide to the displaced persons in their area in the first days after the events of the Lunar New Year and the support of the general public to the often newly-created Red Cross Committees was extremely encouraging.

For the convenience of National Societies, the plan for 1968 is restated below with a budget for the period 1st April to 31st December 1968. It is expected that the number of people which will require rations from the Red Cross will be increased, but it is not considered realistic to budget on making distributions to more than approximately 10,000 persons a month in the present stage of the development of the Provincial Committees.

1968 Plan with Budget for period April/December 1968.

1. Red Cross Committees.-Establishment and development of new Red Cross Committees, particularly in the Centre. To strengthen these and those already operating recruit 25 administrative officers to be financed by the League and assisted by the League Regional Delegates . . . . . . . . .

Dollars

2. Emergency relief distributions.-Local purchases will be supplemented by gifts in kind already received or announced and those that will be provided by sister Societies during the year . . .

45000

3. Milk Stations.-Establish approximately an additional 100 stations in the Centre (serving 300 children each), plus operating costs of these and those already working . . . . . . . . . .

100000

35000 
4. Mobile dispensaries. -6 , each staffed by 2 Vietnamese Red Cross nurses (vehicles already available) ................. . . 9000

5. Fixed dispensaries.-20 staffed by Vietnamese personnel, including some construction costs and medical supplies . . . . . . . . . . . . . . .

6. Training in first aid.-In the Centre as already provided in the Delta . . . . . . . . . 2000

7. Warehouses.-6 regional ... . . . . . . 500

8. League Delegation.-2 delegates in Delta, 3 in Centre, 2 in Saigon and 1 Secretary . . . . . 120000

9. Administration.-Internal transport, etc. . . . 17500

10. Contingency ............ 30000

Total . . 370,000

\section{Relief Programme.}

Since the beginning of the year the following distributions have been carried out by the Republic of Vietnam Red Cross with the assistance of the League Delegation:

$\begin{array}{cccc}\text { Jan. } & \text { Feb. } & \text { March } & \begin{array}{c}\text { Total : } \\ 68\end{array} \\ 68 & 68 & \text { to March } \\ 68\end{array}$

$\begin{array}{rrrrrr}\text { Number of families assisted . . } & 40,069 & 49,746 & 23,083 & 149,609 \\ \text { consisting of (no. of persons) . } & 185,359 & 222,698 & 140,796 & 717,747 \\ \text { Kilos of rice distributed . . . . } & 206,196 & 227,616 & 160,568 & 780,819 \\ \text { Tins of condensed milk distri- } & & & & \\ \text { buted . . . . . . . . } & 59,957 & 65,162 & 26,963 & 208,134 \\ \text { Sleeping mats distributed . . . } & 7,041 & 7,251 & 7,013 & 28,346 \\ \text { Metres of cloth distributed . . . } & 14,580 & 126,875 & 67,477 & 321,227 \\ \text { Soap pieces distributed . . . . } & 1,493 & 3,268 & 9,556 & 98,085\end{array}$




\section{Milk Stations.}

As previously reported, the milk station programme was seriously disrupted towards the end of last year by a breakdown in the supply of powdered milk. A new consignment was received in January and shipped out to the Provincial Committees. However, very few of the milk stations had resumed their activities before the Têt offensive when all schools were closed. Further supplies of milk have now been distributed so that the milk stations can open again once the schools resume, which was planned for the 1st April.

\section{Personnel.}

At the end of March the League Chief Delegate left Saigon for Norway after almost eleven months service. The League Delegation now consists of eight members.

\section{General.}

The part played by the Republic of Vietnam Red Cross in relieving the suffering of the civilian victims of the present conflict has impressed everyone and it is most important that they be assisted to expand their organisation to cover all the Provinces. The League would be grateful to receive any additional funds which sister Societies may be able to make available to finance the continuation of the 1968 programme. In addition, the Vietnamese Red Cross has submitted plans for the construction in Saigon of a Red Cross Convalescent Home for children who can be discharged from hospital if adequate care is available. Also as has already been reported, the Vietnamese Red Cross is going to build an enlarged Amputee Centre on its premises in Saigon and would like to have an orthopaedic workshop to supplement the government workshop as many of the amputees have to remain very many months in the Red Cross centre before they can be fitted with their artificial limbs. The League would be pleased to share with any interested Societies more details concerning these two projects. 
ICRC PROGRAMME

\section{Personnel.}

The ICRC Delegation in Saigon consists of the head of delegation and two mobile teams each comprising one doctor-delegate and one visiting delegate.

\section{Visits to places of detention.}

During the first quarter of 1968 the ICRC Delegates have visited the prisoner of war camps at Bien-Hoa, Can-Tho, Da-Nang, Phu-Quoc and Qui-Nhon, the reception centres at Nui-Dat (in Australian hands), Dong-Tam, Can-Tho, Chu-Lai, Phy-Bay and Da-Nang (in American hands) and the camp at Da-Nang (in Korean hands). They have also visited North Vietnamese prisoners detained by the Americans at Da-Nang, as well as at the CongHoa military hospital.

The number of prisoners thus visited is 10,540. At the conclusion of their visits, during which they could speak freely and without witness to any prisoners of war they chose, the Delegates made known to the detaining authorities their observations and requests and later submitted written reports.

\section{Medical needs.}

On the 29th February 1968, the ICRC doctor-delegate and the League's Chief Delegate accompanied the Minister of Health and a Republic of Vietnam Red Cross official on a visit to the civilian hospital at Hué.

This hospital, with a capacity of 1,100 beds, was about $30 \%$ destroyed. The plight of the injured during the Têt offensive was dramatic-abandoned to their fate for three weeks many died of tetanus and gas gangrene. During this visit 300 patients were in the hospital while the severely injured had been evacuated to Da-Nang. The following urgent needs were ascertained: surgical instruments (particularly for brain surgery); blood; oxygen cylinders; Phisoex (blood substitute); Penicillin; condensed milk; developers for X-ray films. 
On the other hand it was stated that the provision of medical teams was not necessary. Plans to reconstruct the hospital are being considered for which international assistance may later be needed.

With funds provided to the ICRC by certain National Societies and organisations, and in agreement with the League, a substantial quantity of surgical instruments and medical supplies was given to the Hué hospital.

The ICRC was also able to distribute blood plasma thanks to a gift from the Netherlands Red Cross during the first days of the Têt offensive, and at the same time contributed Sw. fr. 100,000 to the Republic of Vietnam Red Cross emergency milk distribution programme.

\section{Democratic Republic qf Vietnam}

Between the 18th and 21st March $1968 \mathrm{Mr}$. Olof Stroh, Secretary General of the Swedish Red Cross, visited the Red Cross Society of the Democratic Republic of Vietnam in Hanoi to discuss ways in which his Society could provide additional and more effective assistance. He has confirmed that the Red Cross Society of the Democratic Republic of Vietnam is very active and has close relations with its Ministry of Health, which is providing a very successful nation-wide health service. The Red Cross is said to have 120,000 active volunteers working mainly with first aid and general hygiene, including digging of pits, arrangements for laundry and latrines, etc. Red Cross volunteers also take part in the birth control programme, which presents most impressive figures. In 1964 the percentage of births was $3.64 \%$, in 1967 it was $2.5 \%$ and the estimated figure for 1968 is $2.4 \%$. The death rate is extremely low, namely $0.7 \%$. The Red Cross, at the local level, also gives assistance to individuals who have been struck by disaster.

Mr. Stroh further reported:

"The general system of public health and medical care seems to be built on a principle of decentralisation and an ambition to 
use all means available co-ordinating them in a way allowing the highest degree of economy in the use of highly qualified personnel and material. Thus first-aid normally is given by Red Cross volunteers. If needed, the patient will be transported from one of the many first aid posts to a district hospital where a doctor's aid with two years training will be responsible. If he is not able to give the needed treatment the patient will be transported to a bigger hospital (regional) where the professional capacity is higher. If the number of patients at the district hospitals is big they will be attended by mobile teams for surgery, going out from the regional hospitals.

The medical principles are most interesting. They can be characterised as a combination of modern scientific medical care and traditional methods. For instance they use for mass vaccinations endo-dermic application of multi purpose vaccines which seem to be more complicated than those used in western medicine. The advantage is said to be that vaccinations can be made by unqualified personnel, they can be made very fast, there is said to be no contra-indications and also the duration of the immunity is said to be longer and the necessary dose can be given on one occasion.

They have also developed specific types of vaccines such as dead $B C G$ vaccines which it is said can be conserved without refrigeration for 3 to 6 months. They produce sabina vaccine against polio and say that today they have nearly no polio cases. I was told that the progress during the last two years has been as great as during the ten previous years. The number of wounded and dead has decreased. Some examples were given. In 1945 the mortality for women giving birth was 20 per thousand, whilst it had decreased to 0.4 per thousand in 1964. Deathrate amongst babies at birth had decreased from $30 \%$ in 1945 to $2.5 \%$ in 1963 .

Another detail which evoked my interest was the use of very great amounts of serum (' salted ' with potash) in order to prevent shock). These intravenous injections were given under high pressure and in quantities as large as 6 litres in one hour.

Burns were treated with bacillus utilus which was said to be of no harm to the tissue itself and to keep all other infections away. The results were said to be extremely good both as to the final 


\section{IN THE RED Cross WORLD}

result and to the speed of recovery. They use special traditional drugs for ointments and bamboo splints instead of plaster in treatment of fractures, believing this results in faster recovery and less complications.

General remarks were made about material received from abroad and it was stressed that if possible everything should be 'tropic proof'. Only kerosene refrigerators should be sent. When it comes to hospital equipment, only instruments and machinery are required. Concerning transportation it was firmly recommended that this be by Polish ships to Haiphong. "

With the funds which sister Societies have sent to the League, amounting to approximately Sw. fr. 630,000.-, a consignment of multivitamin tablets has been sent to the Democratic Republic of Vietnam Red Cross and shipments of blankets, cloth, children's clothing, medicaments, instruments and medical equipment and probably some first-aid kits and ambulances will shortly go forward.

The field hospital of 60 beds which, thanks to many gifts, the ICRC sent to the Democratic Republic of Vietnam Red Cross in December 1967 has been deeply appreciated due to its mobility and its valuable equipment.

With the funds received by the ICRC as a result of the joint appeal of the 12th February 1968, ${ }^{1}$ and in agreement with the League, a second field hospital will be provided and will be ready to be shipped by sea to Haiphong during the month of June.

\section{NAtional Liberation Front}

A second despatch for the NLF controlled territories has been made via Moscow to Hanoi of a radiographic apparatus, valued at Sw. fr. 32,000.- . On the basis of reports received, it has been decided to use the balance of funds donated by National Societies for the provision of antibiotics and other medicaments and phar-

\footnotetext{
${ }^{1}$ See International Review, March 1968.
} 


\section{IN THE RED CROSS WORLD}

maceutical products. Some first aid kits and medical instruments and supplies may also be sent but news concerning the safe arrival of the first shipment is awaited before despatching further consignments.

The League and the International Committee of the Red Cross are grateful to all National Societies which, either through their intermediary or directly, have aided the sister Societies in Vietnam in their relief operation on behalf of the civilian victims of the war. They are urged to continue to give this action their wholehearted and generous support.

It is the desire of all Red Cross members that peace should be re-established in South East Asia. This, however, will confront the Red Cross with new problems in Vietnam requiring new solutions. At that moment it will be necessary to have rapidly available additional extensive resources. 